\title{
PENGARUH SUBJEKTIVITAS DALAM PENULISAN SEJARAH LOKAL KALIMANTAN TENGAH
}

\section{The Effect Of Subjectivity In Central Kalimantan Local History Writing}

\section{Sumiatie I ${ }^{*}$}

\section{Dewi Ratna Juwita $\mathbf{2}^{2}$}

\section{Yudi Susanto $3^{3}$}

\section{Eny Susilowati $4^{4}$}

*I Universitas PGRI Palangka Raya, Palangka Raya, Kalimantan Tengah, Indonesia

2 Universitas PGRI Palangka Raya, Palangka Raya, Kalimantan Tengah, Indonesia

3 Universitas Negeri Malang, Malang, Jawa Timur, Indonesia

4 Universitas PGRI Palangka Raya, Palangka Raya, Kalimantan Tengah, Indonesia

*email:

sumiatie.mpd@gmail.com

dewiratnajuwita 17@gmail.com

yudi.susanto.1907318@students.um.ac.id

enysusilowati.plk78@gmail.com

\begin{abstract}
Abstrak
Penulisan sejarah lokal berhubungan dengan dua aspek tradisi kesejarahan yang tumbuh dan melekat dalam kehidupan suatu komunitas, yaitu tradisi kesejarahan yang bersifat lisan dan tertulis. Tujuan yang ingin dicapai dalam penelitian ini adalah untuk mendriskripsikan Pengaruh Subjektivitas dalam Penulisan Sejarah Lokal Kalimantan Tengah. Pendekatan yang digunakan dalam penelitian ini adalah metode deskriftif dengan menggunakan pendekatan kualititatif. Berdasarkan hasil analisa dan interprestasi bahwa Tradisi lisan dapat dimanfaatkan sebagai sumber sejarah, dengan menekankan sejauh mungkin keterbatasan-keterbatasan dari tradisi lisan. $\mathrm{Hal}$ ini mengingat bahwa sering terjadi sumber sejarah yang hanya ada berupa tradisi lisan yang diwariskan dari generasi ke generasi berikutnya. Penulisan sejarah lokal Kalimantan Tengah tidak terlepas dari subjektivitas penulis, hal ini terjadi karena sulitnya memperoleh jejak-jejak sejarah yang bersifat tertulis dan lebih banyak menggunakan jejak sejarah lisan.
\end{abstract}

Kata Kunci:

Subjektivitas I

Sejarah 2

Lokal 3

Kalimantan Tengah 4

\section{Keywords:}

Subjectivity 1

History 2

Local 3

Central Kalimantan 4

\begin{abstract}
The writing of local history is related two aspects of the historical tradition that grows and is embedded in the life of a community, such as the oral and written historical traditions. The aim of this research is to describe the influence of subjectivity in the writing of local history in Central Kalimantan. The approach used in this research is descriptive method using a qualitative approach. Based on the results of the analysis and interpretation that the oral tradition can be used as a historical source, by emphasizing as far as possible the limitations of the oral tradition. This is due to the fact that there are often historical sources that only exist in the form of oral traditions that are passed down from generation to generation. The writing of local history in Central Kalimantan is inseparable from the subjectivity of the author, this is because it is difficult to obtain historical traces that are written and mostly use traces of unwritten history.
\end{abstract}




\section{PENDAHULUAN}

Telah banyak batasan tentang rumusan sejarah lokal dilontarkan oleh para ahli, tetapi belum diketemukan kesepakatan secara bulat/memuaskan. Beberapa definisi tersebut antara lain: Sejarah Lokal sebagai suatu bentuk penulisan sejarah dalam lingkup yang terbatas, yang meliputi suatu lokalitas tertentu. Sejarah lokal adalah kisah masa lampau dari kelompok masyarakat tertentu yang berada pada geografis terbatas. Sejarah lokal dikatakan sebagai suatu peristiwa yang hanya terjadi dalam lokasi yang kecil, baik pada desa atau kota-kotatertentu. Sejarah lokal adalah sejarah yang menyangkut sebuah desa/ beberapa desa, sebuah kota kecil/sedang (pelabuhan besar/ibu kota tidak termasuk). Sejarah lokal adalah studi tentang kehidupan masyarakat atau khususnya komunitas dari suatu lingkungan sekitar (neighnorhood) tertentu dalam dinamika perkembangannya dalam berbagai aspek kehidupan manusia. (Sejarah, n.d.)

Sejarah lokal yaitu sejarah yang lebih banyak berbicara tentang masyarakat kecil, tempat, institusi, komunitas dan biasanya objek sejarah lokal sangat dekat dengan kehidupan masyarakat di dalam satu arena.(Brooks, 2008)

Sejarah lokal bisa mencakup peristiwaperistiwa yang memiliki keterkaitan dengan sejarah nasional dan peristiwa-peristiwa khas lokal yang tidak berhubungan dengan peristiwa yang lebih luas seperti nasional, regional, atau internasional. Dengan demikian secara sederhana dapat di katakan bahwa sejarah lokal adalah bidang kajian masa lalu dari suatu kelompok atau masyarakat yang mendiami unit wilayah yang tebatas. Ruang sejarah lokal merupakan lingkup geografis yang dapat dibatasi oleh sejarawan dengan alasan yang dapat diterima oleh semua orang. (Nur Agustiningsih, n.d.)

Berdasarkan beberapa defenisi di atas maka Sejarah lokal dapat di artikan sebagai sejarah daerah tertentu dan sudah lama berkembang di Indonesia. Bahkan sejarah Nasional yang kita miliki sekarang ini bermula dari tradisi sejarah lokal tersebut. Hal ini dapat kita lihat dari berbagai sejarah daerah dengan nama-nama tradisional seperti "babat, tambo, riwayat, hikayat dan sebagainya, yang dengan cara-cara khas (magis, mistis) menguraikan asal usul suatu daerah tertentu.

Dalam hubungannya dengan sejarah nasional, sejarah lokal menyangkut identitas suatu bangsa secara keseluruhan. Dilihat dari sifat pendekatan objeknya serta wujud penggambaran peristiwanya, sejarah lokal sangat bervariasi dari yang bersifat tradisional sampai pada uraian yang bersifat kritis akademis. Hal ini sangat bergantung tujuan penulisannya, juga latar belakang pendidikan penulis sejarah lokal tersebut.

Penulisan sejarah lokal berhubungan dengan dua aspek tradisi kesejarahan yang tumbuh dan melekat dalam kehidupan suatu komunitas, yaitu tradisi kesejarahan yang bersifat lisan dan tertulis. Hal ini dilihat dari kenyataan, bahwa seluruh masyarakat di bumi memiliki suatu cerita atau paling tidak anggapan tentang asal-usul mereka.

Tradisi penulisan sejarah dengan tekanantekanan pada daerah tertentu tersebut masih terus berlanjut sampai sekarang. Namun penulisan sejarah lokal masih dianggap kurang bermutu dilihat dari disiplin ilmu sejarah. Prinsip-prinsip sejarah modern, seperti sikap kritis terhadap sumber-sumber sejarah kurang diperhatikan, karena yang dipentingkan adalah memenuhi rasa cinta daerah yang berlebihan atau hanya memberikan informasi tentang asal-usul (nama) daerahnya. (Ham, 1983)

Bila dilihat dari pernyataan tersebut menunjukkan bahwa penulisan sejarah lokal dianggap kurang memenuhi standar sejarah kritis. Namun demikian, karya-karya penulisan sejarah lokal bukan tidak diperhatikan, bahkan diusahakan untuk ditingkatkan. Hal ini berarti bahwa sorotan terhadap penulisan sejarah lokal tidak perlu berlebihan yang dapat mengurangi gairah peminat sejarah di tingkat lokal, sebab ada beberapa aspek positif yang 
disumbangkan oleh para penulis sejarah lokal seperti dikemukakan oleh I Gde Widja yaitu “pengawetan yang kuno di daerah dan dengan demikian dapat mempertinggi kesadaran sejarah”. (Widja, 1991)

Dalam penulisan sejarah pada umumnya, harus ditunjang oleh sumber-sumber tertulis agar hasil karya lebh obyektif. Bangsa Indonesia, memang suduh cukup lama memiliki sumber sejarah tertulis, tetapi umumnya diperlukan keahlian tamgahan untuk bisa menggunakannya dalam penulisan sejarah lokal. Karena dalam penulisan sejarah lokal, baik isi, sifat uraiannya maupun bahasanya sering memerlukan kemapuan khusus dalam menafsirkan serta menyaring isinya, karena ada kecerendungan mencampuradukan antara fakta sejarah dengan fiksi dalam isinya, cara penguraiannya tidak secara singkat dan jelas dimana banyak kata kiasan dan pengertian simbolik, serta bahasanya sering bersifat teknis bukan Bahasa seharihari.

Disamping sumber-sumber tertulis yang banyak jumlahnya dan secara tidak langsung dapat digunakan, maka masih banyak pula sumber-sumber sejarah yang bersifat tradisi lisan, yang lebih memerlukan kemampuan khusus untuk mengambil fakta-fakta sejarah sebagai bahan penulisan sejarah lokal.

Penulisan sejarah lokal tidak dapat dipisahkan dari budaya suatu masyarakat. Pernyataaan ini dapat dihubungkan dengan penegasan dari Sartono Kartodirdjo yang mengatakan bahwa:

Penulisan sejarah sebagai salah satu bentuk perwujudan kebudayaan tidak dapat dipisahkan dari kehidupan kultur dan karena itu senantisa hidup dan bergerak. Maka dari itu, tradisi itu sebenarnya tumbuh sejalan dengan perkembangan manusia serta kebudayaan. (Kartodirdjo, 1982)

Berdasarkan pendapat tersebut menunjukan bahwa manusia hidup dalam suatu ligkungan tertentu, baik lingkungan alam maupun lingkungan sosial. Dalam mengahadapi lingkungan tersebut, manusia secara lahirlah ingin mengetahui serta menjelaskan realistis lingkungan itu. Realistis yang telah dialami, maupun yang sedang dialami akan menjadi pengalaman masa lampau yang nantinya bisa berupa kejadian-kejadian alamiah seperti banjir, gunung meletus, gempa bumi, kekeringan, dan sebagainya. Realitas tersebut dapat pula berupa kejadian yang besumber dari perbuatan manusia sendiri dalam interaksinya dengan manusia lainnya seperti perang, upacara keagamaan, kegiatan ekonmi, dan lain-lain.

Usaha dan cara memahami serta menjelaskan realitas lingknga tersebut tentu saja sesuai dengan situasi alam pikiran masyarakat di suatu jaman tertentu. Dalam tingkat kehidupan manusia, dimana alam pikiran manusia masih dikuasai oleh cara berpikir magis religus, maka hampir tidak satupun unsur kehidupan yang tidak dikaitkan dengan unsur magis. Namun demikian, cara tersebut tetap dianggap suatu cara menangkap atau mengartikan realitas disekitar manusia. Dengan demikian, cara mereka menjelaskan atau memahami realitas itu bukanlah suatu kesengajaan mengacaukan fakta dengan khayalan, tetapi memang suatu cara mengangkat realitas sesuai dengan alam pikiran mereka,yang selanjutnya mengahasilkan suatu legenda atau dongeng. Sehubungan dengan hal tersebut.

Sebagai aspek budaya, maka kepentingan untuk memahami dan menjelaskan lingkungan sekitar dalam sekaligus sebagai usaha untuk memberi pandangan untuk masyarakat terutama generasi berikutnya dalam menghadapi berbagai kemungkinan dari lingkunannya. Dalam hal inilah, tradisi lisan berfungsi sebagai alat untuk merekam, menyusun dan menyimpan pengetahuan demi pengajaran dan pewarisannya dari satu generasi ke generasi berikutnya. Hal ini dilakukan tanpa kesadaran, tetapi didorong oleh kesenangan untuk menceritakan kembali peristiwa-peristiwa yang sangat berarti bagi kehidupan kelompok, misalnya kesenangan dalam perang, kehebatan kepemimpinan kepala suku, tentang bencana 
alam yang pernah menimpa kelompok dan peristiwaperistiwa penting lainnya.

Kejadian-kejadian seperti disebutkan diatas, selalu diulang-ulang menceritakannya dari satu generasi ke generasi berikutnya. Agar ceritanya lebih menarik, maka disamping diampaikan dengan susunan kata-kata biasa, maka ada pula yang disampaikan dalam bentuk syair dan diberikan tembang (lagu). Dalam masyarakat Dayak ngaju Kalimantan Tengah, kita mengenal istilah "Ngarungut" dan "Sansana" yang merupakan yang disampaikan dalam bentuk tembang yang biasany berisi cerita atau legenda tentang sesuatu peristiwa yang terjadi dimasa lampau.

Isi ceritanya makin lama makin dibumbui dengan imbuhan yang disesuaikan dengan alam pikiran yang bersifat magis religius. Pelaku-pelaku utama cerita, misalnya digambarkan sebagai tokoh yang memiliki kesaktian tertentu, yang mampu melakukan perbuatan yang penuh dengan kegaiban. Bag masyarakat pemilik cerita itu, tentu saja semua dianggap hal yang wajar, dan sesuai dengan naluri untuk menumbuhkan kebanggaan kelompok. Dengan cara demikian, faktafakta ini menjadi makin lama makin kabur oleh lukisanlukisan penuh kegaiban. Namun dilain pihak, dengan cara demikian pengalaman kelompok masa lampau diabadikan dalam benuk cerita atau tradisi secara turun temurun. Dengan demikian, tradisi kesejahteraan dalam masyarakat tradisional mempunyai tempat tersendiri dalam sistem budayanya.

Pengertian "lisan" pada tradisi lisan mengacu pada proses penyampaian sebuah tradisi dengan media lisan. Tradisi lisan bukan berarti tradisi itu terdiri atas unsur-unsur verbal saja, melainkan penyampaian tradisi itu secara turun-temurun secara lisan. Dengan demikian, tradisi lisan terdiri atas tradisi yang mengandung unsur-unsur verbal, sebagian verbal (partly verbal), atau nonverbal (non-verbal). Konsep "tradisi lisan” mengacu pada tradisi yang disampaikan secara turun-temurun dari satu generasi ke generasi lain dengan media lisan melalui "mulut ke telinga". (Sibarani, 2015)

Menghubungkan tradisi lisan dengan sejarah, khususnya sejarah lokal berarti mencoba melihat peranannya sebagai sumber sejarah lokal. Namun penggunaan tradisi lisan sebagai sumber penulisan sejarah lokal, ada keterbatasannya. Adapun keterbatasannya antara lain "sifat anakrinisme dari urutan peristiwanya, yaitu tidak diperhatikannya urutan-urutan waktu terjadinya peristiwa secara benar". (Widja, 199I)

Hal tersebut dapat dimaklumi, karena adanya konsep waktu yang berbeda dengan konsep waktu modern. Konsep waktu yang umumnya terdapat dalam tradisi lisan terutama berkaitan dengan pandangan hidup masyarakat pada waktu itu. Dalam pandangan hidup tersebut, segala suatu di alam ini telah mempunyai tempat masing-masing sesuai dengan klasifikasi kultur magis yang diyakini. Waktu dalam hal ini, hanya untuk menunjukan pergeseran atau peralihan dari satu posisi ke posisi lainnya untuk akhirnya kembali ke posisi semula lagi dalam rangka klasifikasi kultur magis tersebut.

Keterbatasan lain dari tradisi lisan adalah adanya unsur subyektivitas yang lebih besar bila dibandingkan dengan sumber tertulis. Seperti dikeahui, tradisi lisan mengandung pesan-pesan lisan yang diwariskan secara turun-temurun dari generasi ke generasi berikutnya. Makin banyak generasi yang dilalui, maka makin banyak pula unsur subyektivitas yang masuk ke dalamnya. Hal ini disebabkan, sebagai suatu pesan maka tradisi itu haekatnya adalah suatu informasi yang pada waktu penerimaannya, dan proses yang sama terjadi pada pewaris berikutnya. Dalam hal ini terjadi subyektivitas ganda, karena subyektivitas itu sebenarnya datang dari pihak penyampai serta pihak penerimanya. Lain halnya dengan sumber tertulis yang hanya mengalami subyektivitas tunggalnya itu dari penerima saja. Dengan demikian dapat dibayangkan, makin jauh jarak antara pembuat tradisi dengan 
penerima atau pewaris tradisi maka fakta yang dikandungnya akan makin dibumbui dengan pandanganpadangan subyektivitas yang terutama berupa unsurunsur kepercayaan masyarakat. Hal inilah yang menyulitkan dalam usaha mengambil fakta sejarah lokal dari tradisi lisan.

Disamping memiliki keterbatasan sebagaiman telah di sebutkan di atas, sebagai sumber penulisan sejarah tradisi lisan juga memiliki segi positif. Hal ini dikemukan oleh Soeri Soeroto dengan mengatakan bahwa:

"Tradisi lisan sebenarnya memuat informasi yang sangat luas tentang kehidupan sesuatu komunitas dengan berbagai aspeknya”. Dalam hal ini, sumbersumber lain, termasuk sumber tertulis tidak akan mampu menandinginya dalm hal keleluasaan cakupan isinya. Lebih lanjut Soeri Soeroto, mengemukan bahwa "keistimewaan tradisi lisan adalah sifatnya sebagai informasi dari dalam (iternal information)”. (Soeroto, 1980)

Berdasarkan pendapat tersebut menunjukan tradisi lisan dapat dimanfaatkan sebagai sumber sejarah, dengan menekan sejauh mungkin keterbatasan-keterbatasan dari tradisi lisan itu sendiri. Dalam posisi ini, tradisi lisan sebagai sumbr sejarah yang potensial sebagai suatu uraian tentang bagaimana orang menginterpretasi masa lampau.

Dari beberapa uraian di atas, dapat disimpulkan bahawa pada dasarnya tradisi lisan terutama yang dikategorikan sebagai legenda, dapat dimanfaatkan untuk menunjang usaha penyusunan sejarah lokal. Hal ini mengingat bahwa sering terjadi sumber sejarah yang ada hanya tradisi lisan. Dalam kaitanya dengan penulisan sejarah lokal Kalimantan Tengah, tradisi lisan sering digunakan sebagai sumber penulisan sejarah karena fakta-fakta sejarah secara tertulis sangat kurang.

\section{METODOLOGI}

Dalam penelitian diperlukan suatu metode agar kebenaran penulisan dapat dipertanggung jawabkan secara ilmiah. Sehubungan dengan hal tersebut, maka dalam penelitian ini menggunakan pendekatan kualitatif, pengolahan data mengutamakan penghayatan peneliti terhadap interaksi antar konsep yang sedang dikaji secara empiris. Suatu penelitian yang dilakukan dengan maksud memahami fenomena tentang apa yang dialami oleh subjek penelitian misalnya perilaku, persepsi, motivasi, tindakan secara holistik dengan suatu konteks khusus yang alamiah, dan dengan memanfaatkan metode ilmiah. (Prof.Dr. Lexy J. Moleong, 2016)

Penelitian ini adalah penelitian yang menghasilkan data deskriptif berupa kata-kata tertulis atau lisan dari orang-orang dan perilaku yang dapat diamati, bergantung dari pengamatan pada manusia, baik dalam kawasannya maupun dalam peristilahannya. Penelitian ini mengutamakan latar alamiah dan dilakukan untuk menyajikan dunia sosial, dan perspektifnya di dalam dunia dari segi konsep, perilaku, persepsi, dan persoalan tentang manusia yang diteliti. (Hasanuddin, 2015)

Data yang di gunakan dalam Penelitian ini adalah data tradisi lisan, dimana penulis bermaksud untuk menggambarkan atau memecahkan masalahmasalah yang terjadi dimasa sekarang dan peristiwaperistiwa yang terjadi di masa lampau yaitu tentang pengaruh subjektivitas dalam penulisan sejarah lokal Kalimantan Tengah. Data dikumpulkan melalui teknik pencatatan, pengamatan langsung, wawancara dan studi literatur. Selanjutnya data dikelompokkan dan dianalisis berdasarkan analisis deskriftif kualitatif.

\section{HASIL DAN PEMBAHASAN}

\section{Subjektivitas Dalam Penulisan Sejarah Lokal} Kalimantan Tengah

Pilihan pada suatu subjek dipengaruhi oleh sejumlah faktor, baik personal maupun historis : 
pengetahuan yang sudah dimiliki, latar belakang pendidikan dan keluarga, aspek-aspek kehidupan yang sangat menarik perhatian, jumlah orang yang bekerjasama dalam proyek (kerja kelompok menjadi semakin populer terutama di organisasi-organisasi lokal), dan sudah barang tentu tersedianya sumbersumber. Seringkali subjek harus didefinisikan lagi atau paling tidak dimodifikasi ketika bukti baru ditemukan. Beberapa topik mengarah pada ditemukannya sumbersumber yang berlimpah. Dalam hal ini rencana penelitian barang kali harus dikurangi : sebaliknya topik-topik yang lain ternyata kekurangan bukti, dan oleh karena itu lingkupnya harus diperluas. Tetapi halhal ini bukanlah suatu peraturan. Sejumlah kecil dokumen dapat digunakan dengan cerdik untuk mengungkapkan kisah manusia yang menarik. (Dymond, 2006)

Seperti halnya tradisi sejarah lisan, maka tradisi sejarah tertulis juga merupakan sumber utama dari banyak studi sejarah lokal di Indonesia. Tradisi sejarah tertulis ini umumnya terdapat dalam wujud karya sastra (prosa maupun puisi) dan ditulis dalam berbagai bahasa daerah di Indonesia. Karena wujudnya sebagai karya sastra maka ini menjadi perhatian, baik dari ahli-ahli sastra maupun ahli sejarah. Khusus dalam hubungan isinya yang mengandung unsur sejarah, maka di kalangan ahli sejarah diklasifikasikan sebagai suatu bentuk penulisan sejarah yang bersifat tradisional dengan ciri-ciri yang khas terutama kalau dibandingkan dengan penulisan sejarah modern.

Dari beberapa studi di perpustakaan daerah Kalimantan Tengah yang dilakukan oleh penulis, diperoleh beberapa karya-karya sejarah yang dimiliki oleh Kalimantan Tengah, yang dilain pihak dapat menunjang bagi kajian sejarah lokal di Kalimantan Tengah. Untuk memberi gambaran bagaimana banyaknya perbendaharaan naskah-naskah bernilai sejarah, khususnya sejarah lokal di Kalimantan Tengah, akan dipaparkan sebagai berikut:
I. Kalimantan Membangun karangan Tjilik Riwut

2. Kalimantan Memanggil karangan Tjilik Riwut

3. Monografi Daerah Kalimantan Tengah terbitan Depdikbud Provinsi Kalimantan Tengah

4. Menelusuri Jalur-jalur Keluhuran Karangan Hermogenes Ugang

5. Satu Abad Musyawarah Perdamaian Tumbang Anoi (1894-1994)

6. Sejarah \& Budaya Kalimantan Tengah Jilid I sebuah kesaksian oleh T.T. Suan

7. Sejarah \& Budaya Kalimantan Tengah Jilid II sebuah kesaksian oleh T.T. Suan

8. Upacara Tradisional Daerah Kalimantan Tengah Bagian I terbitan Dinas Pendidikan dan Kebudayaan

9. Upacara Tradisional Daerah Kalimantan Tengah Bagian II terbitan Dinas Pendidikan dan Kebudayaan

10. Peranan Nilai Budaya Masyarakat Dayak Ngaju Dalam Memelihara Lingkungan di Provinsi Kalimantan Tengah oleh Drs. Salmon Batuallo

II. Kebudayaan Dayak Aktualisasi dan Transformasi, penerbit Grasindo

Berdasarkan naskah-naskah sejarah lokal tersebut di atas, tentu saja belum menunjukkan keseluruhan dari naskah sejarah lokal Kalimantan Tengah, tetapi dari daftar tersebut telah tergambar tentang keberadaan sejarah lokal di Kalimantan Tengah. Dibandingkan tradisi lisan, sumber sejarah tertulis lokal ini memang lebih menguntungkan bagi perkembangan sejarah, karena uraiannya dalam bentuk tulisan, jadi langsung bisa dibaca dari naskahnya. Namun, dalam prakteknya kesulitan yang dialami dalam penggunaan sumber tertulis, karena sifat uraiannya yang tidak jauh berbeda diantara kedua sumber tersebut. Oleh sebab itu, sangat diperlukan kemampuan serta keterampilan yang boleh dikatakan sama dalam penganalisaannya. 
Sebagai suatu bagian dari perbendaharaan budaya suatu masyarakat atau komunitas, maka tradisi kesejarahan itu baik lisan maupun tulisan dengan sendirinya tidak lepas dari ciri-ciri budaya masyarakat pendukungnya. Demikian pula dengan hasil-hasil penulisan sejarah lokal Kalimantan Tengah, maka dalam pemanfaatannya sebagai sumber sejarah tentu suli diperbandingkan begitu saja dengan sumber-sumber sejarah yang bertolak dengan sistem budaya yang lain. Dalam hubungan ini sering ada usaha membandingkan kedua jenis sumber sejarah, yang umumnya dengan dasar pemikiran bahwa sumber sejarah yang berupa tradisi sejarah lokal sulit atau bahkan tidak mungkin digunakan dalam penyusunan sejarah moderen. Apabila sumber sejarah moderen mengandung gambaran peristiwa yang factual (adanya fakta), sedangkan sumber sejarah lokal tersebut mengabaikan unsurunsur fakta karena terlalu dipengaruhi atau dikaburkan oleh sistem kepercayaan yang dimiliki masyarakatnya. (Widja, 199I)

Anggapan seperti dikemukakan dalam pendapat tersebut di atas, sering menjurus kearah prasangka yang berlebihan tehadap sumber-sumber sejarah lokal yang dipandang kurang bisa dipercaya dank arena itu biasa diabaikan. Sebagai konsekuensinya, menurut Soedjamoko bisa terjadi dikembangkannya cara-cara penafsiran sejarah yang berat sebelah dengan kesimpulan-kesimpulan yang ekstrim. (Soedjatmiko, 1985)

Sebagaimana telah dikemukakan sebelumnya, bahwa memang harus diakui bahwa masyarakat Kalimantan Tengah mempunyai cara-cara khusus dalam memandang peristiwa-peristiwa khusus di lingkungannya sejalan dengan konsep-konsep sosiobudaya jamannya. Salah satu yang dianggap oleh $\mathrm{S}$. Gunawan cukup berpengaruh terhadap karya-karya sejarah lokal adalah "adanya kepercayaan tentang kekuatan "sakti" yang menjadi pangkal dari berbagai peristiwa alam, termasuk yang menyangkut kehidupan manusia”. (S. Gunawan, 1985:7I). Kekuatan sakti ini menampakkan diri dimana-mana dan pada setiap saat. Sifat-sifat kekuatan sakti tersebut bisa bekerja secara otomatis, atau diperlukan orang-orang tertentu untuk mengembangkan atau menggerakkannya. Demikian juga mengenai keberadaannya, juga tidak bisa ditentukan dengan pasti karena kadang-kadang bisa muncul atau lenyap tanpa diketahui asal-usulnya.

Dalam kaitannya dengan nilai subjektivitas dalam penulisan sejarah lokal Kalimantan Tengah, maka nilai-nilai sosio-budaya yang terdapat dalam masyarakat ikut mempengaruhi penulisan sejarah lokal sehingga nilai subjektivitasnya tergambar dalam penulisan sejarah lokal, disamping ada nilai objektivitas yang didasari oleh fakta sejarah.

\section{Pengaruh Subjektivitas Dalam Penulisan Sejarah Lokal Kalimantan Tengah}

Sebagaimana halnya dengan prosedur kerja dalam penulisan sejarah pada umumnya, maka kajian sejarah lokal juga memperhatikan empat langkah utama dalam kegiatannya. Menurut I Gde Widja keempat langkah tersebut adalah:

I. Usaha mengumpulkan jejak atau sumber sejarah

2. Usaha untuk menyeleksi atau menyaring jejak atau sumber

3. Usaha menginterprestasikan hubungan fakta satu dengan fakta lainnya yang mewujudkan peristiwa tertentu

4. Penulisan sejarah (Widja, 199I)

Usaha untuk menelusuri jejak-jejak sejarah sebagai langkah permulaan dari prosedur kerja dalam penulisan sejarah. Jadi kegiatan ini terutama ditujukkan untuk menemukan serta mengumpulkan jejak-jejak dari peristiwa sejarah yang sebenarnya mencerminkan beberapa aspek aktivitas manusia di waktu yang lampau. Oleh karena aktivitas manusia diwaktu lampau itu sangat bervariasi, maka jejak-jejak yang 
ditinggalkannya juga beraneka ragam wujudnya. Untuk memudahkan dalam penulisan sejarah lokal terutama dalam memilih jejak-jejak tersebut, maka biasanya dibuat klasifikasi jenis-jenis jejak atau bukti. Selanjutnya Ong Hok Ham mengemukakan tentang salah satu klasifikasi sederhana dalam penulisan sejarah adalah “pembagian berupa jejak yang ditinggalkan tidak dengan sengaja oleh manusia dalam kegiatannya sehari-hari dan dengan sengaja”. (Ham, 1983)

Adapun yang termasuk jejak yang tidak dengan sengaja misalnya berbagai jenis alat yang memang dibuat dan digunakan untuk tujuan khusus pada jamannya tanpa memikirkan digunakan kelak sebagai bahan mengetahui tentang peristiwa yang sudah lewat. Yang termasuk kelompok ini adalah suratsurat resmi seperti ijasah, surat kawin, surat perjanjian dagang dan sebagainya, yang pada jamannya memang mempunyai fungsi khusus dalam kehidupan seseorang. Surat-surat tersebut kemudian sangat penting untuk menyusun gambaran situasi pendidikan, untuk gambar struktur keluarga, ataupun situasi perdagangan pada jaman ternetu, adalah diluar keinginan pembuat/pemakai dokumen tersebut. Sedangkan mengenai jejak sejarah yang dengan sengaja, memang dibuat orang-orang dari jaman kemudian dari hidup pembuatnya. Sebagai contoh misalnya surat wasiat, daftar silsilah keluarga, prasasti dan sebagainya, dimana kelak di kemudian hari jejak-jejak semacam ini akan sangat bermanfaat untuk menyusun sejarah keluarga atau masyarakat setempat.

Cara pengklasifikasian yang lain adalah pembagian jejak sejarah menjadi jejak "historis" dan "nonhistoris". Jejak historis dapat dikelompokkan lagi menjadi beberapa kategori yaitu non material, jejak material, jejak tertulis dan jejak representasional. Yang termasuk jejak non material adalah berupa berbagai lembaga masyarakat, adat, kepercayaan, tradisi, hal-hal gaib, dongeng, Bahasa dan sejarah yang dimiliki oleh suatu bangsa.
Jejak material yang dengan sendirinya bersifat kongkrit terdiri dari bermacam benda atau barangbanrang lain yang dihasilkan oleh manusia diwaktu yang lampau, seperti berbagai alat rumah tangga, alat pertanian, berbagai jenis mesin, kendaraan, lukisan, patung, dan lain-lain. Sedangkan mengenai sumber tertulis dapat dibedakan antara lain berupa tulisan tangan seperti surat, catatan harian, kisah perjalanan, dan berupa cetakan seperti surat kabar, majalah, buku, pamphlet, dan lain-lain. Selanjutnya jejak representasional adalah jejak yang bisa mewakili jejak lain. Sebagai contoh, poto atau lukisan yang kalau di lihat dari bendanya adalah jejak material, tetapi sekaligus dapat mewakili jejak lainnya, yaitu gambaran suasana tertentu yang terdapat dalam poto atau lukisan.

Dari jejak sejarah yang telah disebutkan di atas, semuanya penting unuk penulisan sejarah lokal, terutama sumber atau jejak tertulis. Secara keseluruhan jejak tertulis ini biasanya disebut dokumen yang secara singkat bisa diartikan sebagai informasi yang terekam dalam berbagai wujud, misalnya berupa tulisan tangan, terketik atau tercetak pada kertas, tertera pada gelas ataupun logam, terukir pada kayu atau batu, pada filem, pita audio atau pada disket computer. Secara khusus dokumen dapat berupa tulisan seperti memori, uraian asal-usul, laporan perjalanan, biografi, surat, naskah pidato, surat-surat resmi, dan sebagainya.

Dengan demikian dapat disimpulkan dalam penelusuran jejak sejarah yang merupakan langkah awal dalam melakukan penulisan sejarah lokal, disamping pengetahuan yang luas dalam berbagai karakteristiknya, juga diperlukan ketrampilan khusus.

Namun yang menjadi permasalahan adalah seberapa jauh sejarah lokal mengandung unsur sejarah, pada hakekatnya sudah menjadi perdebatan di kalangan pihak-pihak yang mengadakan studi tentang nakah sejarah lokal, unsur subyektivitas tidak dapat dihindari 
seperti dikemukan oleh alfian yang menyatakan bahwa "ada pencampuran antara fakta dan fiksi didalamnya". (Ibrahim, 198I) disamping hal tersebut, hambatan yang dihadapi dalam penulisan sejarah lokal adalah "Sulit mengharapkan tersedianya sumber-sumber sejarah lokal yang begitu bervariasi”.

Dalam hubungannya dengan penulisan sejarah lokal Kalimantan tengah, maka Sangat sulit diharapkan tersedianya dokumen-dokumen tentang peristiwa dimasa lampau sebagai sumbe-sumber sejarah lokal yang tersimpan sebagai arsip-arsip yang siap digunakan dalam penulisan sejarah lokal. Disamping itu, di Kalimantan tengah masih kurang tersedianya buktibukti tertulis di perpustakan yang khusus menyimpan koleksi sebagai dokumen yang ada kaitannya dengan masa lampau. Dengan demikian, dalam penulisan sering terjadi sumber-sumber sejarah lokal di Kalimantan Tengah yang tersedia terutama berupa tradisi-tradisi atau cerita-cerita, baik yang sudah tertulis maupun yang bersifat lisan yang diturunkan dari generasi ke genarasi berikutnya. Bahkan dalam beberapa kasus penulisan sejarah lokal di Kalimantan Tengah, sumber sejarah yang ada hanyalah orang-orang, baik yang langsung mengalami peristiwanya atau mendengar lebih banyak tentang sesuatu peristiwa tersebut.

Bertitik tolak dari uraian di atas, maka dalam penulisan sejarah lokal Kalimantan Tengah tidak terlepas dari pengaruh subyektivitas dari penulis. Hal ini terjadi karena sulitnya diperoleh jejak-jejak sejarah lokal yang bersifat tertulis dan lebih banyak menggunakan jejak sejarah lisan. Disamping itu, sumber-sumber sejarah lokal Kalimantan Tengah bukan semata-mata dari sumber asli maka tidak mengherankan dalam penulisannya sering tampak mencampurkan antara kenyataan dengan dongeng mitologi, pikiran yang melatarbelakangi penuturan kisah ceritanya. Yang penting, penulis memiliki sikap kritis yang tinggi, sehingga mampu memisahkan mana unsur fakta dan mana unsur subjektivitas yang mengandung unsur dongeng. Sikap kritis ini juga diperlukan dalam interpretasi fakta-fakta sejarah lokal Kalimantan Tengah sehingga gambaran sejarah lokal yang dihasilkan dapat dipertanggung jawabkan. Kemampuan menerapkan sikap kritis inilah akan sangat dibantu oleh unsur subjektivitas dalam penguasaan konsep-konsep teoiritis sejarah lokal Kalimatan Tengah. Dengan demikian, menunjukkan bahwa adanya usaha untuk menyambungkan gambaran fiksi dari jaman lampau dengan gambaran peristiwa nyata yang terjadi kemudian. Selanjutnya Hoesein Djajadiningrat, mengemukakan bahwa "Naskah-naskah seperti babat sebenarnya sedikit banyak merupakan uraian sejarah (Mengandung unsur sejarah) yang selalu mengalami proses penulisan kembali yang didasarkan pada rumusrumus tertetu”. (Nuralam, 2019)

Dari pendapat ini menunjukan bahwa dalam penulisan sejarah lokal merupakan uraian dari sejarah tetapi sudah mengalami proses penulisan kembali didasarkan adanya pengaruh subyektivias penulis. Hal ini terjadi pula dalam penulisan sejarah lokal Kalimantan Tengah, unsur subyektivitas tidak bisa dihindari karena kurang tersedianya bukti-bukti sejarah yang bersifat tertulis, sedangkan sumber yang ada lebih banyak bersifat sumber lisan yang diturunkan dari generasi ke generasi berikutnya.

\section{KESIMPULAN}

Sejarah lokal merupakan suatu bentuk penulisan sejarah dalam ruang lingkup yang terbatas meliputi lokalitas tertentu. Dalam hubungannya dengan sejarah lokal Kalimantan Tengah, maka penulisan sejarah lokal hanya berkaitan dengan sejarah yang terjadi di Provinsi Kalimantan Tengah. Ada beberapa hal yang perlu diperhatikan sebagai dasar pengelompokan sejarah lokal yaitu tujuan penulisan sejarah lokal, latar belakang pendidikan penyusun, sifatsifat pendekatan metodologis yang digunakan, dan aspek-aspek kehidupan yang dijadikan sasaran utama 
studi sejarah lokal. Sedangkan dilihat dari dasar tujuan penulisan sejarah lokal yang berkaitan dengan latar belakang pendidikan penulis, maka dapat dikelompokkan lima jenis penulisan sejarah lokal yaitu sejarah lokal tradisional, sejarah lokal diletantis, sejarah lokal edukatif inspiratif, sejarah lokal kolonial, dan sejarah lokal kritis analitis.

Tradisi lisan dapat dimanfaatkan sebagai sumber sejarah, dengan menekankan sejauh mungkin keterbatasan-keterbatasan dari tradisi lisan. Hal ini mengingat bahwa sering terjadi sumber sejarah yang hanya ada berupa tradisi lisan yang diwariskan dari generasi ke generasi berikutnya. Dalam hubungannya dengan penuisan sejarah lokal Kalimantan Tengah, tradisi lisan sering digunakan sebagai sumber penulisan sejarah karena fakta-fakta secara tertulis masih kurang.

Penulisan sejarah lokal Kalimantan Tengah tidak terlepas dari subjektivitas penulis, hal ini terjadi karena sulitnya memperoleh jejak-jejak sejarah yang bersifat tertulis dan lebih banyak menggunakan jejak sejarah lisan. Disamping itu, sumber-sumber sejarah lokal Kalimantan Tengah ditulis bukan semata-mata dari sumber yang asli. Maka tidak mengherankan dalam penulisannya sering mencampuradukkan antara kenyataan dengan dongeng atau mitologi dari masyarakat yang disampaikan secara turun temurun.

\section{UCAPAN TERIMA KASIH}

Kami mengucapkan banyak terima kasih kepada Perpustakaan Daerah Kota Palangka Raya, Perpustakaan Universitas PGRI Palangka Raya, Perpustakaan FKIP Universitas PGRI Palangka Raya yang sudah membantu dalam pengumpulan data dan informasi, serta Bapak Dekan Fakultas Keguruan dan IImu Kependidikan Universitas PGRI Palangka Raya yang telah memberikan izin penelitian.

\section{REFERENSI}

Brooks, P. (2008). How To Research Local History. How To Books.

Dymond, D. (2006). PENULISAN SEJARAH LOKAL: Sebuah Pedoman Praktis (Writing Local History A Pratical Guide).

Ham, O. H. (1983). Sejarah Lokal. Depdikbud.

Hasanuddin, W. (20I5). Kearifan Lokal Dalam Tradisi Lisan Kepercayaan Rakyat Ungkapan Larangan Tentang Kehamilan, Masa Bayi, Dan KanakKanak Masyarakat Minangkabau Wilayah Adat Luhak Nan Tigo. Kembara: Jurnal Keilmuan Bahasa, Sastra, Dan Pengajarannya, I, 198-204.

Ibrahim, A. T. (198I). Sebuah Catatan Tentang Bagaimana Lokalnya Sejarah Lokal. Depdikbud.

Kartodirdjo, S. (1982). Beberapa Persoalan Sekitar Sejarah Indonesia. Yayasan Kanisius UGM.

Nur Agustiningsih, S. P. (n.d.). Pengembangan Media Video Pembelajaran Candi Muara Jambi Berbasis Sejarah Lokal Pada Mata Kuliah Sejarah Indonesia Hingga Abad 15 Program Studi Pendidikan Sejarah Universitas Batanghari Jambi. 320-333.

Nuralam, A. (2019). Historiografi Banten Dalam Pandangan Hoesein Djajadiningrat. UIN SMH BANTEN.

Prof. Dr. Lexy J. Moleong, M. (2016). Metodologi Penelitian Kualitatif (Edisi Revisi). PT. Remaja Rosdakarya Offset.

Sejarah, P. (n.d.). SEJARAH LOKAL: ( PENGERTIAN, KONTEN, dan. I-II.

Sibarani, R. (20I5). Pendekatan Antropolinguistik Terhadap Kajian Tradisi Lisan. RETORIKA: Jurnal Ilmu Bahasa, I(I), I. https://doi.org/I0.22225/jr.vlil.9

Soedjatmiko. (1985). Kesadaran Sejarah dan Pembangunan. LP3ES.

Soeroto, S. (1980). Penulisan Sejarah Lokal Pemikiran Tentang Pelaksanaannya. Fakultas Sastra Dan Kebudayaan UGM.

Widja, I. G. (I99I). Sejarah lokal suatu perspektif dalam pengajaran sejarah. Penerbit Angkasa. 